\title{
Corrigendum: Ritual, myth and transnational giving within the Zimbabwe Assemblies of God Africa in Johannesburg, South Africa
}

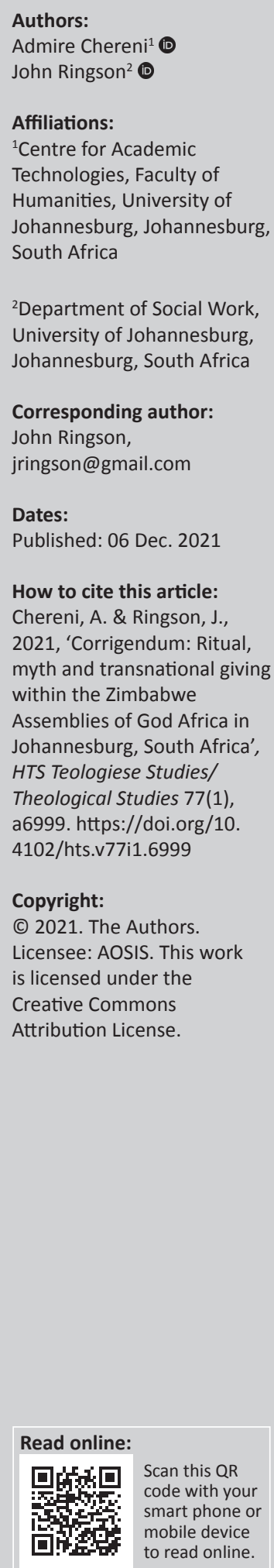

In the version of this article initially published, Ringson, J. \& Chereni, A., 2020, 'Ritual, myth and transnational giving within the Zimbabwe Assemblies of God Africa in Johannesburg, South Africa', HTS Teologiese Studies/Theological Studies 76(3), a5860. https://doi.org/10.4102/hts. v76i3.5860, the order of authors was given incorrectly. The correct order should be Admire Chereni as first author and John Ringson as second author. The correct author order is hereby updated in the 'Authors' and 'How to cite this article' sections.

The incorrect funding information was also provided on page 10. The funding information section is hereby updated:

\section{Funding information}

The article draws on insights generated during Admire Chereni's doctoral fieldwork, which was funded by a German foundation, the Zeit Stiftung. The conference version benefited from a workshop entitled 'The moral dimensions of economic life in Africa', which was fully funded by the Nordic Africa Institute.

This correction does not alter the study's findings of significance or overall interpretation of the study's results. The authors apologise for any inconvenience caused. 